\section{Strawberry Growth and Photosynthetic Responses to Paclobutrazol}

\author{
Dennis E. Deyton', Carl E. Sams', and John C. Cummins ${ }^{2}$ \\ Department of Plant and Soil Science, The University of Tennessee, \\ Knoxville, TN 37901
}

Additional index words. Fragaria $\times$ ananassa, growth retardant, photosynthesis

Abstract. Foliar sprays of increasing concentrations $(0,75,150,300,600$, and 1200 mg-liter ${ }^{-1}$ ) of paclobutrazol were applied to 'Cardinal' strawberry plants (Fragaria $\times$ ananassa Duch.) 35 days after transplanting. The plants were established in August in cultivated plots for measurement of paclobutrazol effects on first year growth or in a double-row hill system on black polyethylene-covered raised beds for 2 nd year measurements. Increasing the paclobutrazol concentration reduced the number of runners, decreased runner length, and limited biomass partitioned into daughter plants. By the end of the first growing season, paclobutrazol had increased lateral crown development but reduced leaf area per treated plant. Root growth was reduced by concentrations $>600$ mg.liter ${ }^{-1}$. Treatment with 75 to $300 \mathrm{mg}^{-1 i t e r}{ }^{-1}$ increased total plant dry weight by $33 \%$ to $46 \%$. The following spring, plant growth was decreased by $\geq 300 \mathrm{mg}^{-1 i t e r}{ }^{-1}$. Yield was increased by all treatments, except $1200 \mathrm{mg} \cdot \mathrm{liter}^{-1}$. Leaf net photosynthesis increased within 12 days after treatment with paclobutrazol and was higher than in the controls the next summer. Leaf stomata1 conductance also increased the first year and was significantly higher the 2 nd year after treatment. The optimum concentration of paclobutrazol for strawberries appears to be between 150 and $300 \mathrm{mg}^{\circ} \mathrm{liter}^{-1}$.

The high density plastic-culture system for strawberry production is being adapted to the upper southern United States (Poling, 1989). In this annual planting system, plants are established in late summer or fall in black polyethylene-covered raised beds and fruit the following spring. Runners that form must be removed, usually by hand. Various chemical growth retardants, including maleic hydrazide (Denisen, 1956; Hitz and Brown, 1956), chlormequat (Guttridge et al., 1966), and daminozide (Sachs et al., 1972) reduce runner formation but have had detrimental effects on strawberry yield or quality.

The gibberellin biosynthesis inhibitor paclobutrazol applied as a soil treatment (Braun and Garth, 1986; Hanzlik and Williams, 1987) or as a foliar spray (McArthur and Eaton, 1987; Stang and Weis, 1984) can suppress runner development during the year of treatment. Total fruit yield and berry size have not been affected adversely by paclobutrazol applied before (Ramina et al., 1985) or during bloom (Stang and Weis, 1984). Applications near bloom delayed fruit maturity (Ramina et al., 1985; Stang and Weis, 1984) during the year of treatment. Information is limited on the effect of paclobutrazol on fallestablished plants and on the crop the fol-

Received for publication 14 May 1990. We wish to acknowledge ICI Americas, Inc. for supplying the paclobutrazol used in these experiments. We appreciate the assistance of Bill Sanders, Statistician, in analysis of data. The cost of publishing this paper was defrayed in part by the payment of page charges. Under postal regulations, this paper therefore must be hereby marked advertisement solely to indicate this fact.

'Associate Professor.

${ }^{2}$ Research Associate. lowing spring. Archbold and Houtz (1988) found that $250 \mathrm{mg}$ paclobutrazol/liter applied to foliage 1 month after establishment did not affect plant biomass the following year but delayed yield.

Ramina et al. (1985) reported that paclobutrazol plus surfactant enhanced photosynthesis of strawberry during the season of application. Other researchers (Archbold and Houtz, 1988) found that strawberry leaf chlorophyll per unit area was increased but net photosynthetic $(\mathrm{Pn})$ rate was reduced 3 months after treatment with $250 \mathrm{mg}$ paclobutrazol/liter. However, treated plants had 18\% higher Pn than control plants 12 months after treatment.

The objectives of this study were to determine: 1) the effects of foliar applications of paclobutrazol on growth and photosynthesis during the season of application and the subsequent spring, and 2) the optimum concentration of paclobutrazol for reducing runner development without decreasing yield.

Cold-stored, dormant 'Cardinal' strawberry plants were transplanted 20 Aug. 1986 , into a Holston (fine-loamy, siliceous, thermic Typic Pacleudits) soil at the Univ. of Tennessee Plant Science Field Laboratory, Knoxville. In Expt. 1, dormant plants were planted in cultivated plots (no plastic) at a spacing of $0.9 \mathrm{~m}$ between plants and $1.4 \mathrm{~m}$ between rows. A foliar spray of paclobutrazol was applied to runoff at $0,75,150,300$, 600 , or $1200 \mathrm{mg} \cdot \operatorname{liter}^{-1}$ (plus $0.1 \%$ Tween 20) 35 days after planting. Treatments were arranged in a randomized complete block design (RCB) with five replications and five plants per plot. All runners were removed before treatment. Any runners that formed after treatment were allowed to establish in soil until winter. Inflorescences were removed before treatment and periodically during the remaining growing season. Total runners per plant were counted, and the plants were dug in Dec. 1986 and partitioned into leaf, crown, and roots of the parent plant and of the daughter plants. Leaf areas were measured with a Decagon area measurement system (Decagon Devices, model ITC-48, Pullman, Wash.). The partitioned parts were dried at $70 \mathrm{C}$ to constant weight in a forcedair convection oven.

In Expt. 2, plants were established on the same date as those of Expt. 1 in black polyethylene mulch covered beds $15 \mathrm{~cm}$ high and $\approx 50 \mathrm{~cm}$ wide at the top. Plants were placed in double rows $30 \mathrm{~cm}$ apart with $25 \mathrm{~cm}$ between plants within a row. Each plot was $4.6 \mathrm{~m}$ long with $1.4 \mathrm{~m}$ between row centers and contained 36 transplants. Paclobutrazol was applied at the same foliar spray rates on the same date as in Expt. 1. Treatments were arranged in a RCB design with six replications. Inflorescences were removed periodically in 1986. Runners were removed before treatment and also removed and counted on 20 Oct. and 4 Nov. One plant from each row was randomly selected and the fourth to sixth trifoliate leaf was tagged on each plant. On 8 and 16 Oct. 1986, the net photosynthetic rates $(\mathrm{Pn})$ of the center leaflet of the fourth to sixth leaf from the base were measured with an ADC model LCA-2 portable infrared gas analyzer (Analytical Development, London). The leaf stomatal conductance (Cs) was measured with a LI-COR Model 1600 (LICOR, Lincoln, Neb.) steady state porometer. The data for the two dates were combined due to a lack of treatment-date interaction and analyzed by regression. The same measurements were also taken 23 and 30 June and 7 July 1987 on the center leaflet of the topmost fully expanded leaf. The data were again combined and analyzed in the manner described.

The strawberry beds were covered with a spunbound polyethylene mulch from Dec. 1986 until Mar. 1987. Plants were rated for percentage open bloom during early bloom, 13 Apr. 1987. Three plants per plot were

Table 1. Growth of 'Cardinal' strawberry daughter plants from parent plants treated with paclobutrazol.

\begin{tabular}{|c|c|c|c|c|c|}
\hline \multirow{3}{*}{$\begin{array}{l}\text { Paclobutrazol } \\
\left(\text { mg-liter }^{-1}\right)\end{array}$} & \multicolumn{5}{|c|}{ Total daughter growth/parent plant } \\
\hline & \multirow{2}{*}{$\begin{array}{l}\text { Daughter } \\
\text { plants } \\
\text { (no.) }\end{array}$} & \multirow{2}{*}{$\begin{array}{l}\text { Leaf } \\
\text { area } \\
\left(\mathrm{cm}^{2}\right)\end{array}$} & \multicolumn{3}{|c|}{ Dry wt $(\mathrm{g})$} \\
\hline & & & $\overline{\text { Shoot }}$ & Root & Total $^{Y}$ \\
\hline 0 & 5.0 & 514 & 7.6 & 2.7 & 10.3 \\
\hline 75 & 2 & 385 & 5.6 & 4.4 & 9.9 \\
\hline 150 & 2.6 & 455 & 5.7 & 3.2 & 8.9 \\
\hline 300 & 1.6 & 262 & 3.2 & 2.6 & 5.7 \\
\hline 600 & 1.4 & 201 & 2.7 & 2.8 & 5.4 \\
\hline 1200 & 1.1 & 87 & 1.3 & 2.2 & 3.5 \\
\hline Line: & ** & $* *$ & $* *$ & NS & $* *$ \\
\hline uadratic & 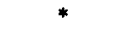 & NS & NS & NS & NS \\
\hline
\end{tabular}

${ }^{2}$ Totals for daughter plants arising from a single parent plant.

"Total of root and shoot dry weights.

NS. $* * * *$ Nonsignificant or significant at $P=0.05$ or 0.01 , respectively. 
Table 2. First year growth of parent 'Cardinal' strawberry plants in response to paclobutrazol.

\begin{tabular}{|c|c|c|c|c|c|c|c|c|c|}
\hline \multirow{4}{*}{$\begin{array}{l}\text { Paclobutrazol } \\
\left(\mathrm{mg} \cdot \text { liter }^{-1}\right)\end{array}$} & \multicolumn{4}{|c|}{ Leaf characteristics } & \multirow{4}{*}{$\begin{array}{c}\text { Lateral } \\
\text { crowns } \\
\text { (no.) }\end{array}$} & \multirow{3}{*}{\multicolumn{4}{|c|}{ Plant dry wt (g) }} \\
\hline & \multicolumn{2}{|c|}{ Per leaf } & \multicolumn{2}{|c|}{ Per plant } & & & & & \\
\hline & \multirow{2}{*}{$\begin{array}{c}\text { Dry wt } \\
\text { (g) }\end{array}$} & \multirow{2}{*}{$\begin{array}{l}\text { Area } \\
\left(\mathrm{cm}^{2}\right)\end{array}$} & \multirow{2}{*}{$\begin{array}{l}\text { Area } \\
\left(\mathrm{cm}^{2}\right)\end{array}$} & \multirow[b]{2}{*}{ No. } & & & & & \\
\hline & & & & & & Leaf & Crown & Root & Total \\
\hline 0 & 0.55 & 62 & 819 & 13.3 & 2.0 & 7.3 & 1.6 & 2.5 & 11.4 \\
\hline 75 & 0.60 & 71 & 1125 & 15.9 & 2.6 & 9.5 & 2.8 & 3.0 & 15.2 \\
\hline 150 & 0.60 & 70 & 1271 & 18.2 & 3.5 & 11.0 & 3.3 & 2.5 & 16.7 \\
\hline 300 & 0.60 & 68 & 1206 & 17.6 & 3.4 & 10.1 & 3.5 & 2.5 & 16.1 \\
\hline 600 & 0.47 & 56 & 859 & 15.4 & 3.6 & 7.7 & 3.3 & 1.8 & 12.8 \\
\hline 1200 & 0.42 & 47 & 560 & 12.0 & 3.2 & 5.2 & 3.2 & 1.5 & 10.0 \\
\hline Linear & * & $*$ & * & NS & NS & $*$ & NS & $*$ & NS \\
\hline Quadratic & * & NS & NS & $* *$ & * & $*$ & $*$ & NS & NS \\
\hline
\end{tabular}

Ns, ****Nonsignificant or significant at $P=0.05$ or 0.01 , respectively.

Table 3. Partitioning of growth in Apr. 1987 of 'Cardinal' strawberry plants grown on plastic and treated with paclobutrazol in Sept. 1986.

\begin{tabular}{|c|c|c|c|c|c|c|c|c|c|c|}
\hline \multirow{3}{*}{$\begin{array}{l}\text { Paclobutrazol } \\
\left(\mathrm{mg} \cdot \mathrm{liter}^{-1}\right)\end{array}$} & \multicolumn{2}{|c|}{$\begin{array}{c}\text { Leaf } \\
\text { characteristics }\end{array}$} & \multirow{2}{*}{\multicolumn{2}{|c|}{$\begin{array}{l}\text { Leaf } \\
\text { growth/ } \\
\text { plant }\end{array}$}} & \multirow{3}{*}{$\begin{array}{c}\text { Lateral } \\
\text { crowns } \\
\text { (no.) }\end{array}$} & \multirow{2}{*}{\multicolumn{5}{|c|}{ Plant dry wt (g) }} \\
\hline & \multirow{2}{*}{$\begin{array}{c}\text { Dry wt } \\
(\mathrm{g})\end{array}$} & \multirow{2}{*}{$\begin{array}{l}\text { Area } \\
\left(\mathrm{cm}^{2}\right)\end{array}$} & & & & & & & & \\
\hline & & & $\mathrm{cm}^{2}$ & No. & & Leaf & Crown & Inflorescence & Root & Total \\
\hline 0 & 0.74 & 77 & 2610 & 34.1 & 4.5 & 24.9 & 11.8 & 6.3 & 4.4 & 47.4 \\
\hline 75 & 0.63 & 61 & 2360 & 38.5 & 4.5 & 24.2 & 12.5 & 6.3 & 4.4 & 47. \\
\hline 150 & 0.56 & 59 & 2430 & 41.0 & 4.9 & 22.6 & 12.5 & 6.6 & 4.2 & 45.9 \\
\hline 300 & 0.51 & 50 & 1850 & 37.2 & 4.3 & 18.3 & 10.5 & 4.9 & 3.2 & 36.9 \\
\hline 600 & 0.38 & 35 & 1650 & 44.3 & 6.0 & 17.5 & 10.2 & 3.2 & 3.0 & 33.9 \\
\hline 1200 & 0.36 & 35 & 1230 & 34.0 & 4.1 & 13.0 & 8.5 & 1.9 & 2.7 & 26.1 \\
\hline Linear & $* *$ & $* *$ & $* *$ & NS & NS & $* *$ & $*$ & $*$ & $* *$ & $* *$ \\
\hline Quadratic & $* *$ & $* *$ & NS & NS & $*$ & NS & NS & NS & NS & NS \\
\hline
\end{tabular}

NS,****Nonsignificant or significant at $P=0.05$ or 0.01 , respectively.

Table 4. Yield in 1987 of 'Cardinal' strawberry plants grown on plastic and treated with paclobutrazol in Sept. 1986.

\begin{tabular}{cccc}
\hline \hline \multirow{2}{*}{$\begin{array}{c}\text { Paclobutrazol } \\
\left(\text { mg-liter }^{-1}\right)\end{array}$} & \multicolumn{2}{c}{ Yield } & Berry wt \\
\cline { 2 - 3 } & Fruit/plant & $\mathrm{t}^{*} \mathrm{ha}^{-1}$ & $(\mathrm{~g})$ \\
\hline 0 & 39.2 & 15.9 & 7.1 \\
75 & 45.7 & 18.7 & 7.2 \\
150 & 51.7 & 19.2 & 6.5 \\
300 & 52.1 & 19.5 & 6.6 \\
600 & 44.2 & 17.1 & 6.8 \\
1200 & 30.6 & 12.2 & 7.0 \\
Linear & $* *$ & $* *$ & $\mathrm{NS}$ \\
Quadratic & $* *$ & $* *$ & $*$ \\
\hline NS.****Nonsignificant or significant at $P=0.05$ \\
or 0.01, respectively.
\end{tabular}

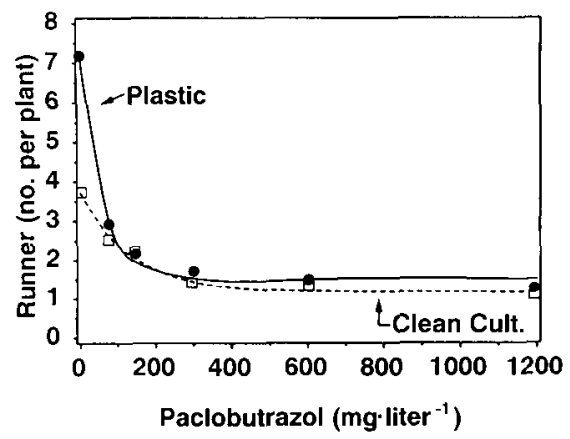

Fig. 1. Effect of paclobutrazol on number of runners of 'Cardinal' strawberry grown on plastic or in clean cultivation. The mean values (mean of 180 plants) of plants grown on plastic are indicated by . The $\mathrm{R}^{2}$-like value of the asymptotic equation $\left[\mathrm{Y}=1.50+5.68 \mathrm{e}^{-0.17 \text { conce. }^{2}}\right]$ is 0.99 . The mean values (mean of 25 plants) of plants grown in clean cultivation are indicated by $\square$. The $R^{2}$-like value of the asymptotic equation $\left[\mathrm{Y}=116+2.56 \mathrm{e}^{\text {(0.00736conce) }}\right]$ is 0.81 . removed 16 Apr. 1987 and partitioned into leaf, crown, root, and inflorescence components. They were dried and weighed as previously described. Fruit were harvested, counted, and weighed at maturity (27 Apr.29 May 1987) from the remaining plants of each plot. Fruit soluble solids concentration (SSC) was determined using a hand-held refractometer for a subsample of fruit collected 17 May from each plot. Fruit acidity was determined by titrating $5 \mathrm{~g}$ of puree, diluted with $12.5 \mathrm{ml}$ of distilled water, with 0.1 $\mathrm{NaOH}$ to an endpoint of $\mathrm{pH} 7.0$.

Strawberry plant growth and dry-matter partitioning during the first growing season (1986) were greatly influenced by paclobutrazol concentration. Runner development was suppressed by paclobutrazol. The number of runners developing on plants grown on plastic was reduced asymptotically as concentration increased, with $75 \mathrm{mg} \cdot$ liter $^{-1}$ resulting in a $60 \%$ reduction and $1200 \mathrm{mg} \cdot \mathrm{liter}^{-1}$ in an $84 \%$ reduction (Fig. 1). The length of runners on plants grown on clean-cultivated soil in Expt. 1 was also reduced asymptotically by paclobutrazol (Fig. 2). Treatment with 600 or $1200 \mathrm{mg} \cdot \mathrm{liter}^{-1}$ reduced runner length to only a few centimeters, resulting in a compact clump of parent plant and daughter plants. Daughter plant growth may have been influenced by the effect of paclobutrazol on the parent plant and/or by uptake from paclobutrazol residual in the soil. Total leaf area, shoot dry weight, and total dry weight of all daughter plants from a single parent were reduced by increasing paclobutrazol concentration (Table 1). Root dry weights were not influenced by treatment, although plants receiving $>150 \mathrm{mg} \cdot$ liter appeared to have fewer, thicker roots.

Development of parent plants was greatly influenced the first growing season. For plants grown on clean-cultivated soil and allowed to develop runners, the number of lateral crowns per parent plant and the total dry weight partitioned into crown were increased by paclobutrazol (Table 2). Mean leaf area and total leaf area per plant were larger and dry weight per plant was higher than the control for plants treated with 75,150 , or 300 mg.liter ${ }^{-1}$. Archbold and Houtz (1988) reported that $250 \mathrm{mg} \cdot$ liter $^{-1}$ did not influence leaf area or dry weight at 3 months after application on plants that had runners removed periodically. Root dry weight was reduced on plants treated with 600 or 1200 $\mathrm{mg} \cdot$ liter $^{-1}$ (Table 2). Total dry weight accumulation of the parent plant was reduced at $1200 \mathrm{mg} \cdot$ liter $^{-1}$ and was higher than that of the control at 75,150 , and $300 \mathrm{mg} \cdot$ liter $^{-1}$. The paclobutrazol treatments of 75 to 300 $\mathrm{mg} \cdot$ liter $^{-1}$ appeared to result in partitioning of dry matter into the parent plant in lieu of runner production. Paclobutrazol treatment with 600 or $1200 \mathrm{mg} \cdot$ liter $^{-1}$ also resulted in partitioning of less dry matter into roots than into shoots during the first year.

The paclobutrazol effects were evident the following spring for the plants grown on plastic. Crown dry weight was reduced by 300, 600, and $1200 \mathrm{mg} \cdot$ liter $^{-1}$ and increased by 75 and $150 \mathrm{mg} \cdot$ liter $^{-1}$, but there were no consistent effects on number of lateral crowns among concentrations (Table 3). Runners had been removed as they developed the previous year; thus, the increased number of lateral crowns in Expt. 1 due to paclobutrazol was probably a result of runner suppression. Mean leaf area and dry weight, total leaf area and dry weight, inflorescence dry weight, root dry weight, and total crown and plant dry weight were reduced by concentrations of 300 to $1200 \mathrm{mg} \cdot$ liter $^{-1}$. The reduced dry matter partitioned into the inflorescence at the time of sampling may have been due to the more compact nature of the inflorescence or to the slight delay in inflorescence development.

Paclobutrazol applied in 1986 affected yield the following spring. Application of 75 to $600 \mathrm{mg} \cdot$ liter $^{-1}$ increased the number of berries per plant by $12 \%$ to $32 \%$ (Table 4 ). Yields of plots treated with 150 and $300 \mathrm{mg} \cdot$ liter $^{-1}$ were $>20 \%$ higher than the control. However, as yield increased, berry size declined. Treatment with $1200 \mathrm{mg} \cdot$ liter $^{-1}$ reduced the number of berries and yield. No differences in fruit SSC or titratable acidity were found at maturity; the ranges were $5.5 \%$ to $7.2 \%$ for SSC and 4.7 to $6.7 \mathrm{ml}$ of titratable acidity per $5 \mathrm{~g}$ of puree. Previous research (Ramina et al., 1985) showed trends toward increases in yield and berry size with no effect on SSC when paclobutrazol was applied before flowering.

High rates of paclobutrazol delayed fruit maturity. Plants receiving $1200 \mathrm{mg} \cdot$ liter $^{-1}$ had a prolonged harvest period (Fig. 3). Plants receiving 150,300 , or $600 \mathrm{mg} \cdot$ liter $^{-1}$ had a slight delay in fruit ripening. The prolonged harvest may have been partially due to a slight 
Table 5. Leaf gas exchange responses of 'Cardinal' strawberry plants treated with paclobutrazol on Sept. 1986.

\begin{tabular}{|c|c|c|c|c|}
\hline \multirow[b]{2}{*}{$\begin{array}{l}\text { Paclobutrazol } \\
\left(\mathrm{mg} \cdot \text { liter }^{-1}\right)\end{array}$} & \multicolumn{2}{|c|}{$1986^{x}$} & \multicolumn{2}{|c|}{$1987^{y}$} \\
\hline & $\begin{array}{c}\mathrm{Pn} \\
\left(\mathrm{mg} \mathrm{CO} / \mathrm{dm}^{2} \text { per } \mathrm{h}\right)\end{array}$ & $\begin{array}{c}\text { Leaf } \\
\text { conductance } \\
\left(\mathrm{s}^{\prime} \mathrm{cm}^{-1}\right)\end{array}$ & $\underset{\left(\mathrm{mg} \mathrm{CO} / \mathrm{dm}^{2} \text { per } \mathrm{h}\right)}{\mathrm{Pn}}$ & $\begin{array}{c}\text { Leaf } \\
\text { conductance } \\
\left(\mathrm{s} \cdot \mathrm{cm}^{-1}\right)\end{array}$ \\
\hline $\begin{array}{r}0 \\
75 \\
150 \\
300 \\
600 \\
1200\end{array}$ & $\begin{array}{l}24.3 \\
24.8 \\
28.1 \\
26.1 \\
27.8 \\
28.5\end{array}$ & $\begin{array}{l}0.205 \\
0.209 \\
0.220 \\
0.218 \\
0.226 \\
0.241\end{array}$ & $\begin{array}{l}18.2 \\
21.0 \\
21.7 \\
21.7 \\
21.7 \\
24.9\end{array}$ & $\begin{array}{l}0.398 \\
0.481 \\
0.483 \\
0.477 \\
0.473 \\
0.492\end{array}$ \\
\hline $\begin{array}{l}\text { Linear } \\
\text { Quadratic }\end{array}$ & $\begin{array}{l}* * \\
\text { NS }\end{array}$ & $\begin{array}{l}\text { NS } \\
\text { NS }\end{array}$ & $\begin{array}{l}* * \\
* *\end{array}$ & * \\
\hline
\end{tabular}

${ }^{2}$ Data are means of five replications and two measurement dates (6 and 16 Oct.)

'Data are means of six replications and three measurement dates (23 and 30 June, and 8 July)

Ns.****Nonsignificant or significant at $P=0.05$ or 0.01 , respectively.

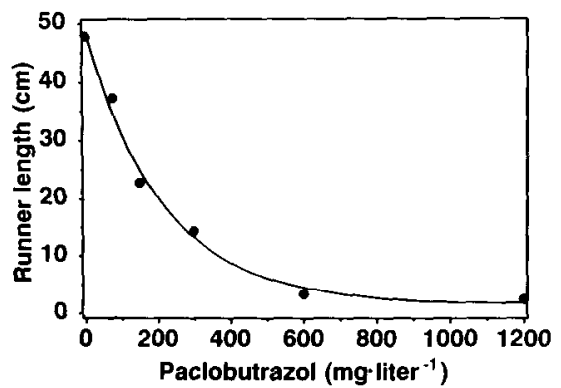

Fig. 2. Effect of paclobutrazol on runner length of 'Cardinal' strawberry during the year of application. Means of 25 plants. The $\mathrm{R}^{2}-$ like value of the asymptotic equation [Y $-1.69+$ $46.9 \mathrm{e}^{(-0.00467}$ conce) $]$ is 0.81 .

( $<1$ day) delay in bloom period noted for the highest concentration.

Net photosynthesis was higher 12 days after treatment with paclobutrazol than in control plants (Table 5). Archbold and Houtz (1988) reported a decline in Pn when measured at 3 months after treatment. Ramina et al. (1985) reported increased leaf photosynthetic efficiency during the season of treatment. They speculated that delayed fruiting may have stimulated the higher Pn. Although Archbold and Houtz (1988) noted an $18 \%$ increase in Pn in June of the year following treatment, in our study, Pn rates remained higher in response to paclobutrazol for 40 days after the last harvest. Paclobutrazol was reported to increase leaf chlorophyll per unit area

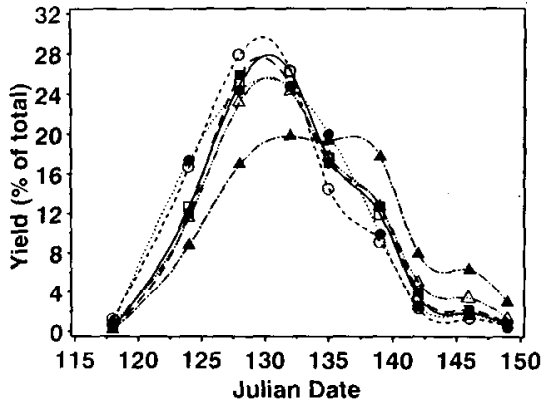

Fig. 3. Percent of total yield at various dates in 1987 of 'Cardinal' strawberry plants grown on plastic and treated with $0(\bigcirc--\bigcirc), 75$

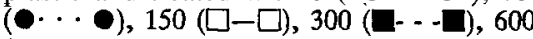
$(\triangle \cdots-\cdots \Delta)$, or $1200\left(\Delta^{*}-\cdot \Delta\right) \mathrm{mg}$ paclobutrazol/liter in 1986 .

(Archbold and Houtz, 1988) at 3 and 12 months after treatment. It appears that paclobutrazol increases Pn the first season as well as the subsequent spring for plants planted on plastic in late summer.

Leaf stomatal conductance tended to increase with paclobutrazol concentration during the autumn. Leaf stomatal conductance increased linearly with paclobutrazol concentration after harvest in 1987. Archbold and Houtz (1988) reported that paclobutrazol at $250 \mathrm{mg} \cdot$ liter $^{-1}$ resulted in increased leaf stomatal conductance at 12 months after treatment, but not at 3 months after treatment.
Growth-suppressing compounds, such as paclobutrazol, may aid in the production of strawberries on plastic. This chemical provides an effective method of reducing runner development. It resulted in more fruit per plant, even when compared with plants on which runners had been removed by hand, and resulted in an increase in yield of up to $22 \%$. Paclobutrazol appears to enhance the photosynthetic capability of strawberry. Based largely on runner control the first season, yield the next spring, and plant growth both seasons, the optimum concentration appears to be 150 to $300 \mathrm{mg} \cdot$ liter $^{-1}$.

\section{Literature Cited}

Archbold, D.D. and R.L. Houtz. 1988. Photosynthetic characteristics of strawberry plants treated with paclobutrazol or flurprimidol. HortScience 23(1):200-202.

Braun, J.W. and J.K.L. Garth. 1986. Strawberry vegetative and fruit growth response to paclobutrazol. J. Amer. Soc. Hort. Sci. 111(3):364367.

Denisen, E.L. 1956. Chemical inhibition of strawberry runners in the matted row. Proc. Amer. Soc. Hort. Sci. 67:312-323.

Guttridge, C.G., H.M. Anderson, and W.S. Stewart. 1966. The control of strawberry runners in the field with CCC. Expt. Hort. 15:9295.

Hanzlik, N.L. and J.M. Williams. 1987. Effects of paclobutrazol on growth responses of strawberries. HortScience 22(5):720. (Abstr.)

Hitz, C.W. and M.S. Brown. 1956. Control of strawberry runner growth with sprays of maleic hydrazide. Proc. Amer. Soc. Hort. Sci. 67:324330

McArthur, D.A.J. and G.W. Eaton. 1987. Effect of fertilizer, paclobutrazol, and chlormequat on strawberry. J. Amer. Soc. Hort. Sci. 112:241246.

Poling, E.B. 1989. Strawberry accents. Fruit South 10(1) 14-15.

Ramina, A., P. Tonutti, and T. Tosi. 1985. The effect of paclobutrazol on strawberry growth and fruiting. J. Hort. Sci. 60(4):501-506.

Sachs, M., E. Izsak, and C. Geisenberg. 1972. Effect of chlormequat and SADH on runner development and fruiting behavior of summerplanted strawberry. HortScience 7(4):384-386.

Stang, E.J. and G.G. Weis. 1984. Influence of paclobutrazol plant growth regulator on strawberry plant growth, fruiting and runner suppression. HortScience 19(5):643-645. 